\title{
PEMANFAATAN DRAINASE (SALURAN) AIR BEKAS LIMBAH RUMAH TANGGA SEBAGAI SOLUSI UNTUK PENURUNAN RESISTANSI PENTANAHAN (GROUNDING)
}

\author{
Dian Eka Putra \\ Universitas Palembang \\ dianekaputra90@gmail.com
}

\begin{abstract}
Abstrac: This study aims to anticipate a high value of grounding resistance by utilizing drainage or waste water from household waste as a planting medium to reduce the value of grounding resistance. The research method used is an experimental method of testing and measuring at field locations. In this study, a round rod electrode is coated with copper, namely testing with one electrode rod and two electrode rods that are installed in parallel or better known as the use of a driven rod. The results showed a decrease in the value of the grounding resistance where the average value for 1 grounding rod was $18.32 \mathrm{ohms}$ and $11.82 \mathrm{ohms}$ for the measurement of 2 grounding rods installed in parallel. From the test results, there was a decrease in the resistance value of $59.52 \%$ for 1 electrode rod and a 51.75\% decrease for 2 electrode rods, where the decrease in the resistance value in the field was caused by factors of water, humidity and used water minerals from household waste. In conclusion, housing with reddish yellow podzolic soil that is clay (high soil resistance) by utilizing water drainage is a solution to reduce grounding resistance.
\end{abstract}

Keywords: Resistance, Drainage, Grounding (Grounding)

\begin{abstract}
Abstrak: Penelitian ini bertujuan untuk mengantisipasi nilai resistansi grounding yang tinggi dapat memanfaatkan drainase atau saluran air bekas limbah rumah tangga sebagai media tanam untuk menurunkan nilai resistansi pentanahan. Metode penelitian yang digunakan adalah metode pengujian dan pengukuran dilokasi lapangan yang bersifat eksprimental Dalam penelitian ini menggunakan jenis elektroda batang bulat yang dilapisi tembaga yaitu pengujian dengan satu batang elektroda dan dua batang elektroda yang di pasang paralel atau yang lebih dikenal dengan penggunaan driven rod. Hasil penelitian menunjukkan terjadi penurunan nlai resistansi pentanahan dimana didapat nilai rata-rata untuk 1 batang Grounding Rod sebesar 18,32 Ohm dan 11,82 ohm untuk pengukuran 2 batang grounding rod yang dipasang secara parallel. Dari hasil pengujian tesebut terjadi penurunan nilai resistasi sebesar 59,52 \% untuk 1 batang elektroda dan Penurunan 51,75\% untuk 2 batang elektroda, dimana penurunan nilai resistansi dilapangan disebabkan faktor air, kelembaban dan mineral air bekas dari limbah rumah tangga. Simpulan, perumahan dengan lahan tanah podsolik kuning kemerahan yang bersifat liat (resistansi tanah yang tinggi) dengan memanfaatkan drainase saluran air menjadi solusi untuk menurunankan resistansi pentanahan.
\end{abstract}

Kata Kunci: Resistensi, Saluran (Drainase), Pentanahan (Grounding)

\section{PENDAHULUAN}

Musim kemarau yang terjadi di Indonesia terjadi diantara bulan april dan berakhir pada awal sepetember tentunya akan memepengaruhi kelembaban tanah yang ada di wilayah Indonesia. Salah satunya di Kelurahan Tanah Mas Kecamatan Talangkelapa Kabupaten Banyuasin. Dimana pada musim kemarau kadar air pada tanah akan berkurang, fenomena ini berpengaruh pada sistem keandalan instalasi listrik yaitu pada sistem pentanahan pada instalasi listrik rumah atau gedung, semakin berkurangya kadar air atau kelembaban akan meningkatkan nilai resistansi pada sistem pentanahan, yang mana dengan resistansi meningkat akan terjadi hambatan tengangan listrik ke bumi (IEEE Std 81, 2012) sehingga akan menimbulkan efek tegangan sentuh dan arus lebih yang memiliki bahaya atau resiko ganguan kesehatan dan jiwa bagi mahluk hidup (Lim et al., 2013). Selain itu tergangguanya kontinyunitas penyaluran energi listrik pada instalasi listrik rumah tinggal atau instalasi listrik gedung bangunan (Putra \& Iswadi, 2021). Ditambah lagi konstruksi pemasangan grounding rod pada rumah tinggal pada pemungkiman masyarakat dipasang atau tanam dibawah Alat Pembatas Pengukur (APP) Energi Listrik atau yang disering dikenal $\mathrm{KwH}$ Meter, ditaman ditanah 
podsolik merah kuning, pada area tanam yang kering sehingga mengahasilkan nilai tingginya resistansi pentanahan. Adapun cara untuk menurunkan nilai resistansi tersebut dengan memanfaatkan drainase muka tanah atau saluran air yang berfungsi untuk menampung dan menyerap air hujan, serta menyalurkan air dari sisa pemakaian rumah tangga (Halim, 2012). Pada umumnya rumahrumah dan perumahan dilengkapi saluran air atau drainase selain tempat penampungan air hujan berfungsi sebagai tempat saluran pembuangan air bekas atau limbah rumah tangga. Dengan memanfaatkan mineral dari limbah rumah tangga, faktor kelembaban, dan genangan air yang ada pada saluran air bekas maka sangatlah cocok sebagai tempat media tanam grounding rod, dimana pada musim kemarau saluran air tersebut selalu menerima air bekas dari sisa pemakaian rumah tangga.

Resistansi pembumian dari elektroda bumi tergantung pada jenis dan keadaan tanah serta pada ukuran dan susunan elektroda (PUIL, 2000). Semakin kecil nilai tahanan pentanahan maka semakin baik pula sistem pentanahannya (Dwi et al., 2019), jika apabila pada praktiknya masih terdapat nilai resistansi yang tinggi diperlukan perbaikan konstruksi sistem penanaman elektroda bumi untuk menurunkan resistasi pentanahan.

Berdasarkan uraian diatas maka dilakukan kajian untuk mengantisipasi nilai resistansi grounding yang tinggi dapat memanfaatkan drainase atau saluran air bekas limbah rumah tangga sebagai media tanam untuk menurunkan nilai resistansi pentanahan.

\section{LANDASAN TEORI}

Nilai dari resistansi pada instalasi pentanahan mempunyai peranan yang sangat penting dalam menyalurkan arus induksi dan arus gangguan, karena nilai tahanan suatu sistem pentanahan merupakan tolak ukur dari baik buruknya suatu sistem pentanahan. Bila nilai resistansi suatu sistem pada instalasi pentanahan terlalu tinggi maka tegangan dan arus induksi atau gagnnguan tidak bisa dialirikan kebumi dengan cepat. Dimana pentanahan berfungsi sebagai mengalirkan tegangan dan arus induksi dari peralatan listrik berbahan logam kebumi (Salam et al., 2017).

Faktor air, kelembaban dan garam menjadi penting untuk penurunan resistansi pentanahan (IEEE Std 81, 2012). Oleh karena itu perlu mendapatkan nilai resistansi pentanahan dan diusahakan sekecil mungkin agar tidak membahayakan orang di sekelilingnya dan tidak menimbulkan kerusakan pada peralatan-peralatan listrik.

\section{METODE PENELITIAN}

Dalam penelitian ini menggunakan jenis elektroda batang bulat yang dilapisi tembaga yaitu pengujian dengan satu batang elektroda dan dua batang elektroda yang di pasang paralel atau yang lebih dikenal dengan penggunaan driven rod (Hizamul-din et al., 2021). Dengan menggunakan rumus-rumus pendekatan yang di pakai untuk menghitung nilai resistansi pentanahan, dari bentuk elektroda batang bulat yang dilapisi tembaga yang ditanamkan tegak lurus kedalam tanah (Putra \& Iswadi, 2021). Kemudian membandingkan dari hasil pengujian penanaman elektroda batang di dalam tanah dengan memanfaatkan tempat saluran air terbuka atau drainase perumahan yang menampung air bekas hasil pembuangan rumah tangga.

Adapun penelitian menggunakan metode pengujian dan pengukuran dilokasi lapangan yang bersifat eksprimental dengan beberapa langkah penelitian. Pertama, peninjauan pada titik lokasi, yang memiliki jenis tanah podsolik merah kunik yang bersifat liat. Kedua, desain Gambar kerja untuk penanaman atau pengujian, pengukuran resistasi pentanahan di saluran air terbuka atau drainase perumahan.

Ketiga, mempersiapkan material dan peralatan berupa Ground rod panjang 1,8 meter diamenter $5 / 8$ inchi dengan dilapisi tembaga dan Bare Coper Condurtor (BCC) diameter $6 \mathrm{~mm}^{2}$, perlengkapan bantu (tools set) dan untuk alat ukur digunakan alat ukur resistansi pentanahan jenis digital atau yang dikenal dengan Digital Earth Tester (Kyoritsu seri 4105A) serta material bantu lainya. 
Keempat, penentuan titik tanam penanaman elektroda batang.

Keenam, pengukuran resistansi pentanahan pada pengujian penanaman elektroda batang disaluran air terbuka atau drainase menggunakan metode tiga titik, dimana 1 batang elektrode memiliki 2 buah titik atau elektrode pasak bantu, menggunakan Digital Earth Tester (kyoritsu 4105A). Ketujuh, pengukuran dimulai pada instalasi grounding rod yang telah ditanam di bawah $\mathrm{kWH}$ meter, dimana nilai resistansi tersebut sebelum memanfaatkan saluran air terbuka (drainase) sebagai tempat pengujian.

Kedelapan, pengujian dengan melakukan penanaman menggunakan 1 batang elektroda besi dilapisi tembaga. Serta dengan menggunakan 2 batang elektroda besi dilapisi tembaga di saluran air terbuka (drainase). Kesembilan, pengukuran resistansi pentanahan pada elektroda batang yang tertanam di saluran air terbuka (drainase) perumahan. Kesepuluh, analisa dari hasil perhitungan dan pengujian serta pengukuran resistansi pentanahan disaluran air terbuka atau drainase perumahan.

\section{HASIL PENELITIAN}

Jenis tanah podsolik merah kuning yang bersifat liat dengan resistansi pentanahan mencapai $100 \Omega$ berikut karakteristik material pentanahan dan jenis tanahan pada penelitian penanaman elektroda batang di saluran air terbuka atau drainase perumahan dengan memanfaatkan air bekas dari rumah tangga.

Tabel 1.

Karakteristik Material Grounding dan Jenis Tanah

\begin{tabular}{clc}
\hline No & Keterangan & Jenis dan Ukuran \\
\hline 1 & Bentuk Eletroda & Batang (drivenrod) \\
\hline 2 & Bahan Elektroda & Besi dilapisi Tembaga \\
\hline 3 & Panjang elektroda & $1,8 \mathrm{~m}$ \\
\hline 4 & $\begin{array}{l}\text { Diameter } \\
\text { elektroda batang }\end{array}$ & $5 / 8$ inch $=0,015875 \mathrm{~m}$ \\
\hline 5 & Jenis Tanah & $\begin{array}{c}\text { Tanah liat, tanah } \\
\text { ladang pada kondisi } \\
\text { lembab }=100 \Omega\end{array}$ \\
\hline 6 & $\begin{array}{l}\text { Jarak tanam } \\
\text { antara elektroda }\end{array}$ & 2 meter. \\
\hline & \multicolumn{2}{c}{}
\end{tabular}

Berdasarkan hasil perhitungan nilai resistansi pentanhan untuk satu batang elektroda pentanahan adalah sebesar 45,3 $\Omega$.

$$
\mathrm{Rp}=\frac{\rho}{2 \pi L} \ln \left(\frac{4 L}{a}-1\right)
$$

Sedangkan berdasarkan hasil perhitungan dengan persamaan 2 (Sunarno, 2006) nilai resistansi pentanahan untuk dua batang elektroda pentanahan adalah sebesar $24,5 \Omega$.

$$
\mathrm{Rp}^{2}=\frac{\rho}{4 \pi L}\left(\ln \frac{4 L}{a}-1\right)+\frac{\rho}{4 \pi s}\left(1-\frac{L^{2}}{3 s^{2}}+\frac{2 L^{4}}{5 s^{4}}\right)
$$

Untuk $\mathrm{s}>L$

Untuk penelitian pengujian dan pengkuran pemasangan batang elektroda pentanahan pada drainase saluran air terbuka, dimana karakterisktik data diambil dari sebelum dan sesudah pengujian pada lokasi perumahan.

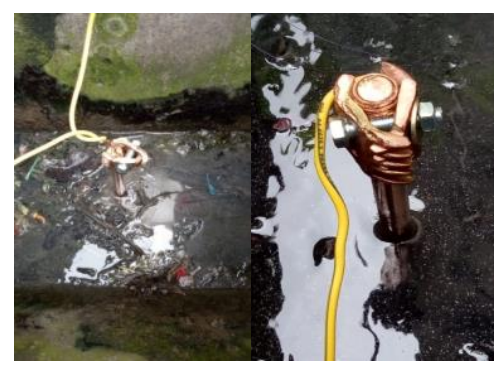

Gambar 1. Penanaman dan Pengukuran di saluran air terbuka

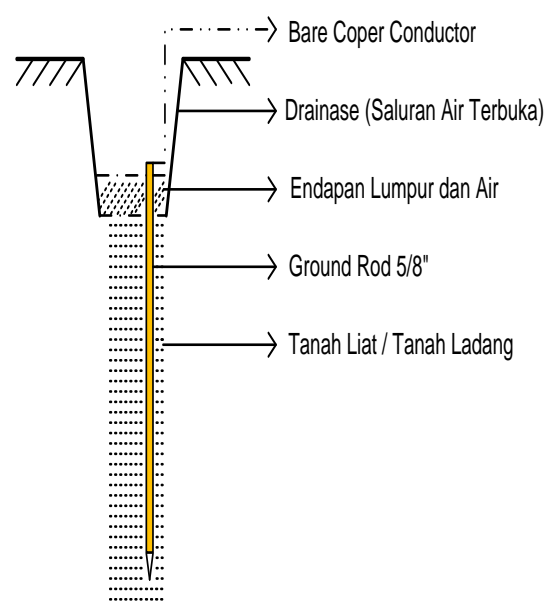

Gambar 2. Skema penanaman 1 batang elektroda pentanahan di saluran air terbuka (drainase) perumahan 


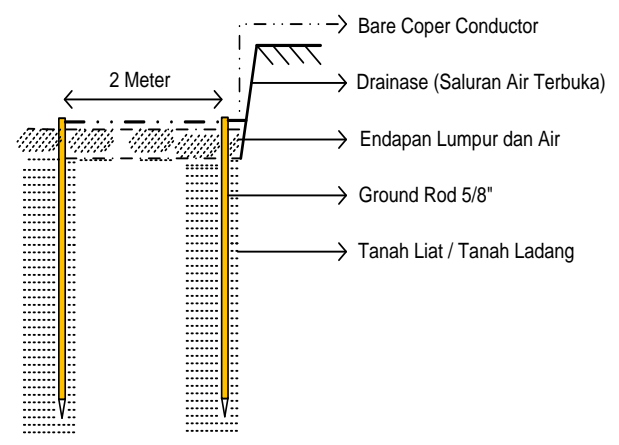

Gambar 3. Skema penanaman 1 batang elektroda pentanahan di saluran air tebuka (drainase) perumahan.

Tabel 2.

Hasil pengukuran tahanan pentanahan

\begin{tabular}{ccccccc}
\hline & & \multicolumn{2}{c}{ Resistan Hasil } & \multicolumn{3}{c}{ Hasil Pengukuran } \\
\cline { 3 - 7 } Norhitungan & Titik Lokasi uji & $\begin{array}{c}\text { 1 Rod } \\
\text { No }\end{array}$ & $\begin{array}{c}\text { 2 Rod } \\
(\Omega)\end{array}$ & $\begin{array}{c}\text { Rod Bawah KWH } \\
(\Omega)\end{array}$ & $\begin{array}{c}\text { 1 Rod } \\
(\Omega)\end{array}$ & $\begin{array}{c}\text { 2 Rod } \\
(\Omega)\end{array}$ \\
\hline 1 & Titik 1 (36/01) & 45,3 & 24,5 & 44,4 & 21,7 & 15,8 \\
\hline 2 & Titik 2 (36/01) & 45,3 & 24,5 & 72,5 & 18,9 & 12 \\
\hline 3 & Titik 3 (01/01) & 45,3 & 24,5 & 74,7 & 21,1 & 13,2 \\
\hline 4 & Titik 4 $(25 / 11)$ & 45,3 & 24,5 & 27,4 & 12,4 & 6,6 \\
\hline 5 & Titik 5 (22/06) & 45,3 & 24,5 & 40,5 & 17,5 & 11,5 \\
\hline
\end{tabular}

Dari Tabel 2. Terjadi perbedaan antara hasil perhitungan dimana hasil perhitungan resistansi pentanahan didapat sebesar 45,3 $\Omega$ untuk 1 batang elektroda pentanahan dan 24,5 untuk 2 batang elektroda pentanahan, diman hasil pengukuran dan pengujian resistansi pentanahan di atas, pengukuran pada insatlasi pentanahan yang dipasang dibawah $\mathrm{kWh}$ meter dengan menggunakan 1 batang elektroda pentanahan memiliki nilai resistansi pentahan lebih besar dari pengujian penanaman elektroda batang di saluran air tebuka atau drainase perumahan yaitu dengan rata-rata 51,9 $\Omega$. Sedangkan dari hasil pengujian dan pengukuran elektroda batang yang tertanam disaluran air terbuka (drainase) dengan 1 batang elektroda pentanahan didapat rata-rata nilai resistansi sebesar $18,3 \Omega$ dan dengan menggunakan 2 batang elektroda pentanahan didapat rata-rata nilai resistansi sebesar $11,8 \Omega$.

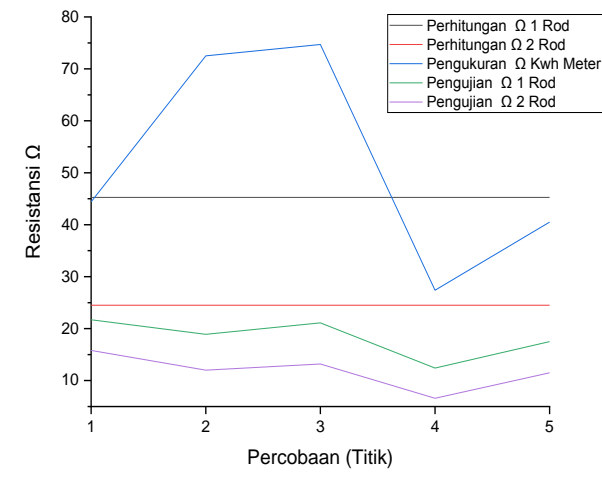

Gambar 4. Grafik hasil pengukuran dan pengujian nilai resistansi pentanahan

Dari Gambar di atas hasil pengukuran nilai resistansi pentanahan dimana pengukuran dan pengujian di lakukan pada saluran air limbah pembuangan di sekitar perumahan atau rumahu pada drainase terbuka.

Setelah dilakukan pengukuran pada instalasi grounding yang terpasang dibawah Alat Pengukur dan Pembatas (APP) atau pada $\mathrm{kWh}$ Meter pada perumahan, didapat nilai resistansi pentanahan tampak lebih besar yaitu rata-rata sebesar 51,9 $\Omega$ dibanding dengan 
perhitungan sebesar 45,3 $\Omega$, hal ini disebabkan oleh kondisi yang kering dan kurangnya kelembaban yang terjadi pada area tanam elektroda batang yang terletak dibawah $\mathrm{kWh}$ meter.

Terjadi penurunan nilai resistansi yang signifikan sebesar $64,70 \%$ dimana didapat nilai rata-rata resistansi dari hasil pengujian dan pengukuran yaitu sebesar $18,3 \Omega$ terhadap dari hasil pengukuran semula pada pentanahan yang dipasang dibawah $\mathrm{kWh}$ meter dengan menggunakan 1 batang elektroda pentanahan, hal ini disebabkan oleh faktor kelembaban yang tinggi, genangan air bekas rumah tangga dan mineral yang terkandung dari air limbah rumah dari hasil pemakaian air rumah tangga.

\section{PEMBAHASAN}

Pengujian yang dilakukan mulai dari perhitungan dan pengukuran maka terdapat perbandingan hasil rata-rata dari perhitungan resistansi pentanahan dengan hasil pengukuran dilapangan di drainase saluran air terbuka, dimana dari hasil perhitungan nilai rata-rata resistansi pentanahan lebih besar yaitu untuk 1 batang Elektroda sebesar $45,3 \Omega$ dan untuk 2 batang eletroda sebesar 24,5 $\Omega$, sedangan dari hasil pengujian dan pengukuran didapat nilai resistansi lebih kecil yaitu untuk 1 batang elektroda sebesar $18,32 \Omega$ dan untuk 2 batang elektroda sebesar $11,82 \Omega$. Menurut Kusrini et al., (2018) suatu pentanahan yang baik adalah yang memiliki hambatan pentahanan yang kecil, karena dengan hambatan yang kecil dapat mengalirkan arus yang berlebih langsung ke tanah. Semakin kecil nilai resistansi pentanahan maka kemampuan mengalirkan arus ke tanah semakin baik sehingga arus gangguan tidak mengalir dan tidak merusak peralatan (setiawan et al., 2018).

Dengan ini membuktikan pengaruh dari mineral air, kelembaban tanah, endapan lumpur dan air dari sisa pemakaian rumah tangga dapat menurunankan resistansi pentanahan dan menjadi solusi untuk menurunkan resistansi pentanahan pada instalasi listrik diperkotaan dan diperumahan.
Hal serupa dikemukan oleh Sunawar (2013), bahwa pentahanan jenis tanah di pengaruhi oleh komposisi tanah, temperatur, kandungan air (kelembaban), dan kandungan kimia dalam tanah. Sistem pentahanan merupakan salah satu faktor penting dalam usaha pengamanan (perlindungan) sistem tenaga listrik saat terjadi gangguan yang disebabkan oleh arus lebih dan tegangan lebih ke bumi (Syakur, 2008).

\section{SIMPULAN}

Perumahan dengan lahan tanah podsolik kuning kemerahan yang bersifat liat (resistansi tanah yang tinggi) dengan memanfaatkan drainase saluran air menjadi solusi untuk menurunankan resistansi pentanahan. Dimana pada drainase terbuka memiliki faktor penurun resistansi pentanahan atau grounding diantarannya kelembaban, air, mineral yang terkandung pada saluran air. Selain pengaruh oleh faktor air dan kelembaban, faktor mineral yang terkadung pada lumpur dan air sisa pemakaian rumah tangga dapat menurunkan nilai resistansi pentanahan.

\section{DAFTAR PUSTAKA}

Dwi, R., Cahyo, N., \& Rahmawati, Y. (2019). Studi Tahanan Pentanahan Menggunakan Campuran Arang dan Garam Dalam Menurunkan Nilai Tahanan Tanah The study of ground resistance using mixture of charcoal. Jurnal Inovasi Pertahanan dan Keamanan, 2(1), 1-12. https://journals.itb.ac.id/index.php/jipk /article/view/12377/4358

Halim, H. A. (2012). Drainase Terapan. Yogyakarta: UUI Pres

Hizamul-din, H. H., Nor, N. M., Ahmad, N. N., Idris, N. F., \& Mahmud, A. (2021). Investigations on the Performance of Various Horizontal Ground Electrodes. Energies, 14(4), 1-12. https://doi.org/10.3390/en14041036

IEEE Std 81. (2012). IEEE Guide for Measuring Earth Resistivity, Ground Impedance, and Earth Surface Potentials of a Grounding System. 
Redline,

$1-192$

https://ieeexplore.ieee.org/servlet/opac ?punumber $=6654223$

Kusrini, N., Bakri, S., Martin, Y., \& Riniarti, M. (2018). Pemanfaatan Bentonit, Kapur dan Limbah Puing Bangunan untuk Meningkatkan Kapasitas Tanah Tropika dalam Menurunkan Resistansi Grounding. Diaspora: Eksakta, 1(1), 21-30. http://pasca.unila.ac.id/wpcontent/uploads/2019/01/6_Eksakta13.pdf

Lim, S. C., Gomes, C., \& Ab Kadir, M. Z. A. (2013). Electrical earthing in troubled environment. International Journal of Electrical Power and Energy Systems, 47(1), $117-128$. https://doi.org/10.1016/j.ijepes.2012.1 0.058

PUIL, 2000. (2000). Persyaratan Umum Instalasi Listrik 2000 (PUIL 2000). Jakarta: BSN

Putra, D. E., \& Iswadi, I. (2021). Pengaruh Pembebanan Terhadap Nilai Resistansi Pentanahan Pada Transformator 250 KVA Gardu BA 0005 PT. PLN (Persero) UP3 Bengkulu ULP Teluk Segara Bengkulu. JURNAL SURYA ENERGY, 5(1), 31-42. https://doi.org/https://doi.org/10.32502 /jse.v5i1.2767

Salam, M. A., Rahman, Q. M., Ang, S. P., \& Wen, F. (2017). Soil resistivity and ground resistance for dry and wet soil. Journal of Modern Power Systems and Clean Energy, 5(2), 290-297. https://doi.org/10.1007/s40565-0150153-8

Setiawan, D., Syakur, A., \& Nugroho, A. (2018). Analisis Pengaruh Penambahan Garam dan Arang Sebagai Soil Treatment dalam Menurunkan Resistansi Pentanahan Variasi Kedalaman Elektroda. TRANSIENT, 7(2), 1-8. https://doi.org/10.14710/transient.7.2.4 $16-423$

Sunawar, A. (2013). Analisis Pengaruh Temperatur dan Kadar Garam
Terhadap Hambatan Jenis Tanah. SETRUM, 2(1), 16-21. https://jurnal.untirta.ac.id/index.php/jis /article/download/233/333

Sunarno, S. (2006). Mekanikal Elektrikal Lanjutan. Yogyakarta: Andi Offset

Syakur, A., Juningtyastuti, J., \& Dermawan, D. (2008). Comparative Analysis of Grounding Resistance Value in Soil and Septictank. TEKNIK, 29(3), 203208.

https://doi.org/10.14710/teknik.v29i3. 1942 